MARQUES, DJ; MATHEUS FILHO, E; BIANCHINI, HC; VERONEZE JUNIOR, V; SANTOS, BR; CARLOS, LA; SILVA, EC. 2020. Tomato production in hydroponic system using different agrofilms as greenhouse cover. Horticultura Brasileira 38: 58-64. DOI - http://dx.doi.org/10.1590/S0102-053620200109

\title{
Tomato production in hydroponic system using different agrofilms as greenhouse cover
}

\author{
Douglas José Marques ${ }^{1} \mathbb{D}$; Edmur Matheus Filho ${ }^{2} \mathbb{D}$; Hudson C Bianchini ${ }^{2} \mathbb{D}$; Valdir Veroneze Junior ${ }^{3 \mathbb{D}}$; \\ Breno Régis Santos ${ }^{3} \mathbb{D}$; Lanamar de A Carlos ${ }^{4} \mathbb{D}$; Ernani Clarete da Silva ${ }^{4} \mathbb{D}$
}

${ }^{1}$ Universidade Federal de Uberlândia (UFU), Monte Carmelo-MG, Brasil; douglasjmarques81@yahoo.com.br; ${ }^{2}$ UNIFENAS, Alfenas-MG, Brasil; edmurmthfilho@gmail.com; hudson.bianchini@unifenas.br; ${ }^{3}$ Universidade Federal de Alfenas (UNIFAL), Alfenas-MG, Brasil; valdirveronezejunior@gmail.com; brenors@yahoo.com.br; ${ }^{4}$ Universidade Federal de São João del Rei (UFSJ), Sete Lagoas-MG, Brasil; lanamar@ufsj.edu.br; clarete@ufsj.edu.br

\begin{abstract}
Protected cultivation has increased over the years. More studies on the benefits of using photoselective agrofilms are necessary. The choice of material to cover the greenhouse is a decisive factor for crop development and production. The aim of this study was to evaluate the effect of diffuser and blue-colored agrofilms on the production of different tomato cultivars of indeterminate growth habit under NFT hydroponic system. A completely randomized design in a $2 \times 3$ factorial scheme (two environments and three cultivars) was used: two agrofilm types (blue and diffuser) and 3 cultivars (Monterrey, Arendell and Totalle). Each plot consisted of 30 plants per treatment, with four replicates. Commercial tomato seedlings of indeterminate growth habit grafted on rootstock cultivar (Shincheonggang) were used. During the experiment, the electrical conductivity, intensity of radiation inside the greenhouse, gas exchange, soluble solids, lycopene content, $\mathrm{pH}$ and fruit production were evaluated. We concluded that the amount of radiation transmitted through the diffuser favors an increase of about $18 \%$ in gas exchange, $12 \%$ in lycopene content and $9.4 \%$ in tomato crop production.
\end{abstract}

Keywords: Lycopersicon esculentum, lycopene, gas exchange, radiation.

\section{RESUMO}

Produção de tomate no sistema hidropônico usando diferentes agrofilmes para cobertura da casa de vegetação

O cultivo protegido tem aumento ao longo dos anos, havendo necessidade de ampliar as pesquisas que comprovem benefícios da utilização de agrofilmes fotosseletivos. A escolha do material para a cobertura da casa de vegetação é fator decisivo para o desenvolvimento da cultura e produção. O objetivo deste trabalho foi avaliar o efeito dos agrofilmes de cor azul e o difusor na produção de diferentes cultivares de tomateiro de hábito de crescimento indeterminado no sistema hidropônico-NFT. Utilizouse o delineamento inteiramente casualizado em esquema fatorial $2 \times 3$ (dois ambientes e três cultivares): dois tipos de agrofilme (azul e difusor) e 3 cultivares (Monterrey, Arendell e Totalle), sendo cada parcela constituída por 30 plantas por tratamento, com quatro repetições. Utilizaram-se mudas comerciais de tomateiro de hábito de crescimento indeterminado enxertadas em porta-enxerto cultivar Shincheonggang. Foram avaliadas durante a pesquisa a condutividade elétrica, intensidade da radiação dentro da casa de vegetação, trocas gasosas, sólidos solúveis, teor de licopeno, $\mathrm{pH}$ e produção de frutos. Conclui-se com a pesquisa que a quantidade de radiação que passa pelo agrofilme difusor favorece um aumento em torno de $18 \%$ as trocas gasosas, $12 \%$ o teor de licopeno e $9,4 \%$ a produtividade da cultura do tomate.

Palavras-chave: Lycopersicon esculentum, licopeno, trocas gasosas, radiação.

Received on May 8, 2019; accepted on January 28, 2020

$\mathrm{T}$ omato is one of the main vegetables grown in Brazil. The Country ranks the ninth position, $2.5 \%$ of production worldwide, being possible to increase its production and commercialization in the next decade (Dossa \& Fucks, 2017).

In Brazil, tomato is cultivated in approximately 22 thousand hectares of protected environment and high tunnels for producing vegetables and cut flowers (Cobapla, 2018), considering that about 10 thousand hectares are located in São Paulo State. Vegetable cultivation in a protected environment is a booming activity in Brazil; its great advantage is the off season production, allowing greater regularization of supply and better product quality (Andrade et al.,
2011).

In Brazil, protected cultivation area has increased along the years, thus more studies on the benefits of using photoselective agrofilms are necessary.

Using polyethylene cover on a greenhouse interferes in microclimate and in radiation and energy balance, resulting in several benefits such 
as earliness, increase in production and plant protection against weather adversities (Cunha et al., 2002).

Agrofilms known as diffusers have in their composition additives which control solar radiation, directly related to the suitability of temperatures (Sousa et al., 2002). According to Papadakis (2000) the ideal material for protected cultivation has to allow $100 \%$ transmission of photosynthetically active radiation, with wavelengths ranging from 0.4 to $0.7 \mu \mathrm{m}$, which is effectively used by plants during the photosynthesis process.

Blue-colored agrofilm can select more favorable wavelengths for plants (PAR radiation), converting the light bands less used by plants in photosynthetic process into more effective wavelengths, such as blue, red and extreme red. Thus, choosing the material for covering a greenhouse is an extremely important factor to maintain crop development, since it can alter solar radiation transmission into the greenhouse, benefiting plants according to their demands (Guiselini et al., 2004).

Tomato plants need maximal light capture to maintain their entire vegetative apparatus and their ability to supply organs (sources and drains), especially fruits, which are key players in the feedback mechanism for their growth (Gary et al., 2003). The luminosity saturation point which establishes the limiting level of photosynthetically active radiation up to the increase in $\mathrm{CO}_{2}$ assimilation should be always observed. Levels of photosynthetically active radiation below limit may restrict photosynthesis and levels above the limit may promote an excessive temperature rise of the plant, with negative consequences on transpiration and photosynthetic rate (Ferrari \& Leal, 2015). However, studies on alterations caused by photoselective agrofilms in vegetable production are still scarce in Brazil.

The aim of this study was to evaluate the effect of blue-colored and diffuser agrofilms on production of different tomato cultivars of indeterminate growth habit under NFT hydroponic system.

\section{MATERIAL AND METHODS}

The experiment was carried out in a greenhouse, at Setor de Olericultura e Experimentação, Engenharia Agronômica at UNIFENAS, AlfenasMG, from April 2 to October 2, 2018.

Two greenhouses, arch-detached type, 9-meter wide, 25-m long and $4.0 \mathrm{~m}$ ceiling height were used. Each greenhouse was covered with blue-colored and diffusing agrofilm, respectively.

The experimental design was completely randomized in factorial scheme $2 \times 3$. The treatments consisted of two covered cultivation environments with different types of agrofilm (blue and diffuser) and three tomato cultivars of indeterminate growth habit (Monterrey, Arendell and Totalle). Each plot consisted of 30 plants, with four replicates.

Blue-colored agrofilm showed the characteristics of photoconverter, microclimate control, light diffuser, antistatic, made with five layers, antivirus and resistant to ultraviolet rays. The diffuser agrofilm was photoselective, antivirus, light diffuser, anti-static and resistant to ultraviolet rays.

We used commercial tomato seedlings of indeterminate growth habit (Monterrey, Arendell and Totalle) on rootstock cultivar Shincheonggang. Plants were conducted in 10 brickworkpatterned channels (cultivation channels), $20-\mathrm{cm}$ wide, $25-\mathrm{cm}$ high, 25-m long, 80-cm spacing and 3\% slope. The authors used $3000 \mathrm{~L}$ water volume for nutrient solution. The solution was time-triggered every 15 minutes, and covered the channels for 15 minutes; then, the timer was turned off and the process was restarted again after 15 minutes. Timer was programmed to apply the nutrient solution three times overnight.

The hydroponic solution was managed weekly late afternoon (5 p.m.). At 8 a.m. electrical conductivity and $\mathrm{pH}$ (ideal values) were measured, $3.5 \mathrm{mS}$ $\mathrm{cm}$ and 6.5 , respectively, completing the solution volume. The nutrient solution used was recommended by Marques et al. (2018).
Cultural practices and phytosanitary management were carried out in the experiment, according to the crop's necessity. Plants were tutored using ribbons, one stem per plant, 35 days after transplanting. Lateral sprouts were eliminated from the $15^{\text {th }}$ day of seedling transplanting every week and defoliation was performed from the beginning of fruit ripening and top pruning was performed above the tenth cluster. Defoliation consists of the removal of old leaves, without physiological activity, aiming to improve aeration, increase photosynthetic efficiency and, mainly, reduce risks of incidence of pests and diseases. Electrical conductivity, radiation intensity inside the greenhouse, gas exchange, soluble solids, lycopene content, $\mathrm{pH}$ and fruit production were evaluated.

At 90 days after seedling transplanting, the authors standardized 2.00-m height cultivation canopy inside the greenhouse, recording quality and quantity of radiation incidence (Espectrorradiômetro Luzchem, SPR4002, Ottawa, Canada) for one hour, measuring the minimum radiation (390) and maximum (790 nanometers).

In order to determine electrical conductivity, nutrient solution samples were collected before and after renovation, every 2 weeks, until the $19^{\text {th }}$ cultivation week, using a digital conductivity meter (Lutron, mod. CD4303).

Gas exchange, liquid photosynthesis, transpiration, stomatal conductance, intercellular $\mathrm{CO}_{2}$ concentration, water use efficiency and instant carboxylation efficiency were evaluated using an IRGA model LI-6400XT, (Li-Cor, Lincoln, Nebrasca, USA). Two plants were randomly obtained from each plot, and sample unit was represented by the sixth leaf counting from the top, totally expanded and mature. Since it is a species which has compound leaves, the first three leaflets of each leaf were used for measuring, totalizing six measures. Saturation irradiance was fixed at 850 $\mu \mathrm{mol} \mathrm{m} \mathrm{m}^{-2} \mathrm{~s}^{-1}$, value defined by a light curve, value which induced maximum photosynthesis. Tomato is a C3 plant, a plant which cyclic mechanism of enzymatic reactions converts $\mathrm{CO}_{2}$ into 
carbohydrates, through the reductive photosynthetic cycle (C3), generating the 3-phosphoglycerate. That is why, the temperature of the IRGA camera was controlled at $28^{\circ} \mathrm{C}$, since in $\mathrm{C} 3$ plants the maximum photosynthesis rate (TMF) is achieved in relatively low radiation intensity, causing no destruction or damage to the photosynthetic apparatus. Measurements were carried out on a 6- $\mathrm{cm}^{2}$ leaf area.

Ten harvests were performed during the experiment, as tomato fruits were becoming ripe. After harvests, fruits were separated and classified (MAPA, 1995). Then, number of fruits and production of marketable fruits were quantified (average 30 plants per plot).

Tomato fruits were stored in thermal boxes and taken under refrigeration to Laboratório de Conservação de Alimentos of Universidade Federal de São João Del-Rei, Sete Lagoas-MG, being prepared and evaluated. All analyses were performed in triplicates. We determined $\mathrm{pH}$ using a potentiometer (AOAC, 2012) with the aid of a Tekna digital $\mathrm{pH}$ meter model T-1000, by direct immersion of the electrode in the crushed and homogenized fresh fruit extract. Total soluble solid contents ( ${ }^{\circ}$ Brix) were determined placing drops of the fresh fruit extract, crushed, homogenized and filtered, on the prism of a Reichert r2MINI digital refractometer. Lycopene content was determined according to the methodology proposed by RodriguezAmaya (2001), which consists of extracting carotenoids using acetone (P.A.) and quantifying these chemical substances using a spectrophotometry at $470 \mathrm{~nm}$. The results were expressed in $\mu \mathrm{g}$ of lycopene per 100 grams fresh mass.

The obtained results were submitted to variance analysis and averages submitted to Scott-Knott test, using SISVAR software according to theories advocated by Ferreira (2011). Afterwards, in order to compare the results, the authors performed statistical joint analysis of the data obtained in each greenhouse.

\section{RESULTS AND DISCUSSION}

The highest radiation intensity was obtained using the blue-colored agrofilm in a wavelength from 454 to $566 \mathrm{~nm}$ and using the diffusing agrofilm in a wavelength from 470 to $630 \mathrm{~nm}$ (Figure 1). The form of electromagnetic waves in the blue agrofilm varied to blue (470 $\mathrm{nm})$, green $(490 \mathrm{~nm})$ and yellow $(585$ $\mathrm{nm})$, reducing to orange, $(585-640 \mathrm{~nm})$ and red $(640-740 \mathrm{~nm})$. For the diffuser, less variation for the wavelengths of blue and orange to red was noticed. In photosynthetically active radiation, light absorption varies depending on the physiological process to blue (435nm)

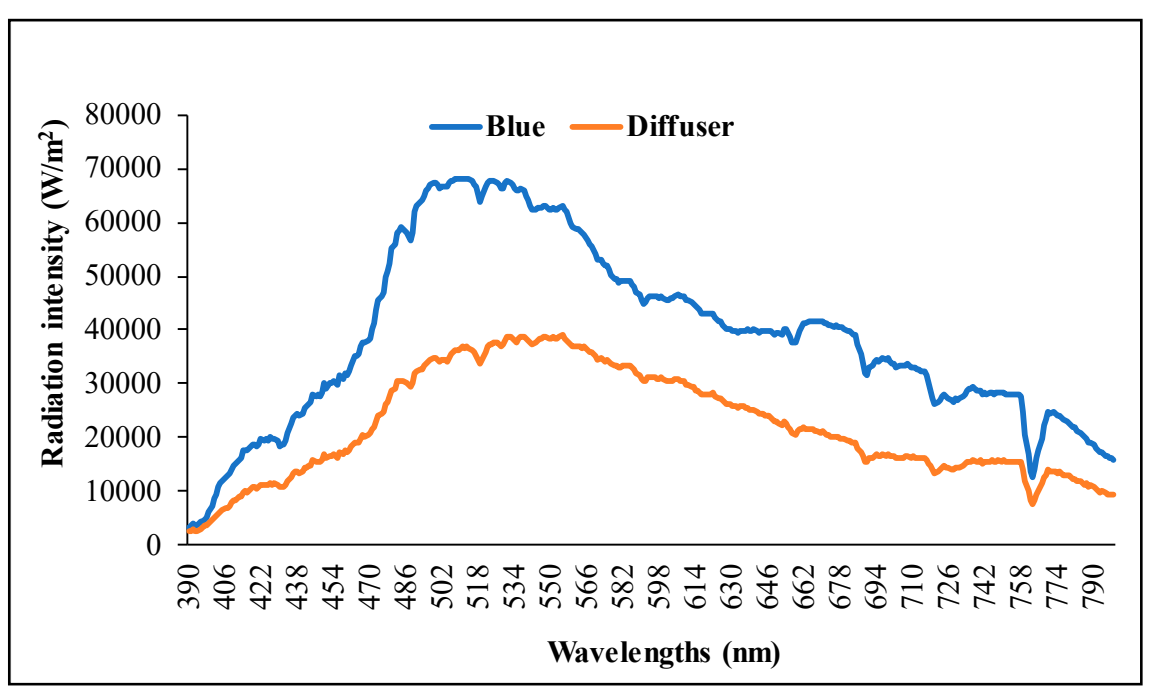

Figure 1. Radiation intensity $\left(\mathrm{W} / \mathrm{m}^{2}\right)$ of blue-colored and diffusing agrofilms in relation to different wavelengths (nm). Alfenas, UNIFENAS, 2018. and red $(675 \mathrm{~nm})$ wavelengths (Kämpf et al., 2000).

We evaluated electrical conductivity (CE) before (Figure 2A) and after (Figure 2B) the preparation of a new nutrient solution of tomato grown under the two types of agrofilm. Throughout cultivation, CE was higher in the treatment where the blue-colored agrofilm was used (Figure 2A). This result may be related to the fact that the blue-colored agrofilm provided very varied wavelengths, which made tomato plants absorb lower quantity of nutrient solution, resulting in higher $\mathrm{CE}$. After changing the nutrient solution, no significant differences were observed in $\mathrm{CE}$ throughout the evaluated weeks (Figure 2B).

Cultivars Arendell and Monterrey showed higher stomatal conductance, liquid photosynthesis and transpiration rates (Figures $3 \mathrm{~A}, \mathrm{~B}$ and $\mathrm{C}$ ) for diffusing agrofilm; for cv. Totalle the highest stomatal conductance, liquid photosynthesis and transpiration rates were found using blue-colored agrofilm (Figures 3A, B and C). Due to higher radiation intensity caused by the blue agrofilm, cvs. Arendell and Monterrey were probably submitted to some type of photoinhibition which reduced stomatal conductance and transpiration, according to observed by Ferraz et al. (2012). These results are in accordance with the ones found in this experiment (Figures 3A, B, C). According to Lima et al. (2010), stomatal behavior determines the transpiration demand by controlling the loss of $\mathrm{H}_{2} \mathrm{O}$ from the leaves to the environment, in the form of water vapor. Liquid photosynthesis is an indicator of carbon assimilation rate (Popov et al., 2003), considering that agricultural productivity is influenced by morphological and physiological traits of photosynthetic organs, such as leaves, and of consuming organs of the photoassimilates, known as drains.

The highest intercellular $\mathrm{CO}_{2}$ concentration $(\mathrm{Ci})$ in tomato leaves was observed with the use of blue agrofilm, for cvs. Arendell, Monterrey and Totalle (Figure 4A). The highest instant carboxylation efficiency was found in cvs. Arendell and Monterrey, using diffusing agrofilm (Figure 4B). 


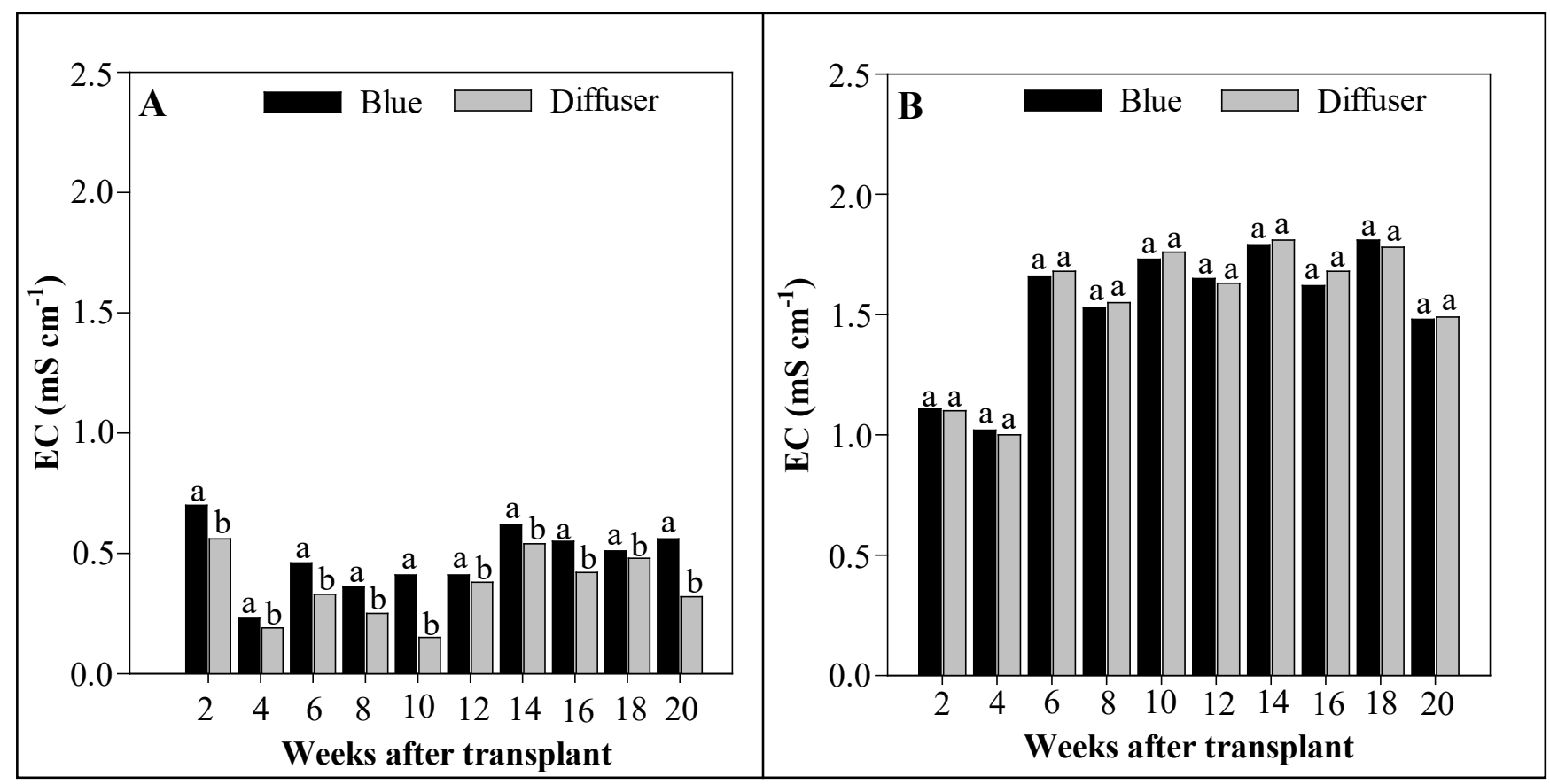

Figure 2. Electrical conductivity evaluated before (A) and after renewing the nutrient solution (B) in tomato crop in relation to the two agrofilms. Alfenas, UNIFENAS, 2018.



Figure 3. Stomatal conductance (A), liquid photosynthesis (B) and transpiration (C) of three tomato cultivars in relation to different agrofilms. Alfenas, UNIFENAS, 2018.

The blue agrofilm was superior when comparing with the diffusing film for water use efficiency (EUA) (Figure 4C). According to Jadoski et al. (2005), an increase in $\mathrm{CO}_{2}$ assimilation rate is related to higher $\mathrm{CO}_{2}$ concentration found in the leaves, which may be related to stomatal closing in response to abiotic stresses. Daley et al. (1989) reported that a reduced stomatal conductance is able to limit $\mathrm{CO}_{2}$ retention rate and, consequently, intercellular $\mathrm{CO}_{2}$ concentration will decrease, due to $\mathrm{CO}_{2}$ consumption by photosynthetic activity.
However, an increase in $\mathrm{CO}_{2}$ content in the greenhouse may cause reduction in stomatal conductance (Shimono et al., 2010). Low stomatal conductance, observed in high $\mathrm{CO}_{2}$ concentrations causes less transpiration, considering that stomatal closing and consequent reduction of normal flow of $\mathrm{CO}_{2}$ towards carboxylation site are one of the main responsible for photosynthesis reduction (Bosco et al., 2009).

In relation to fruit production, the authors observed different responses of the genotypes in relation to the type of agrofilm used to cover the greenhouses. No significant difference was observed for cv. Totalle, whereas cvs. Arendell and Monterrey showed the highest productions when diffusing agrofilm was used (Figure 5A). This fact was due to a better light distribution by the diffusing agrofilm, which maximizes the use of high light intensities. Also, light quality strongly affects plant growth: the light of wavelength in green zone, causes greater elongation of stems and leaves; wavelengths mostly in red and blue zones reduce 


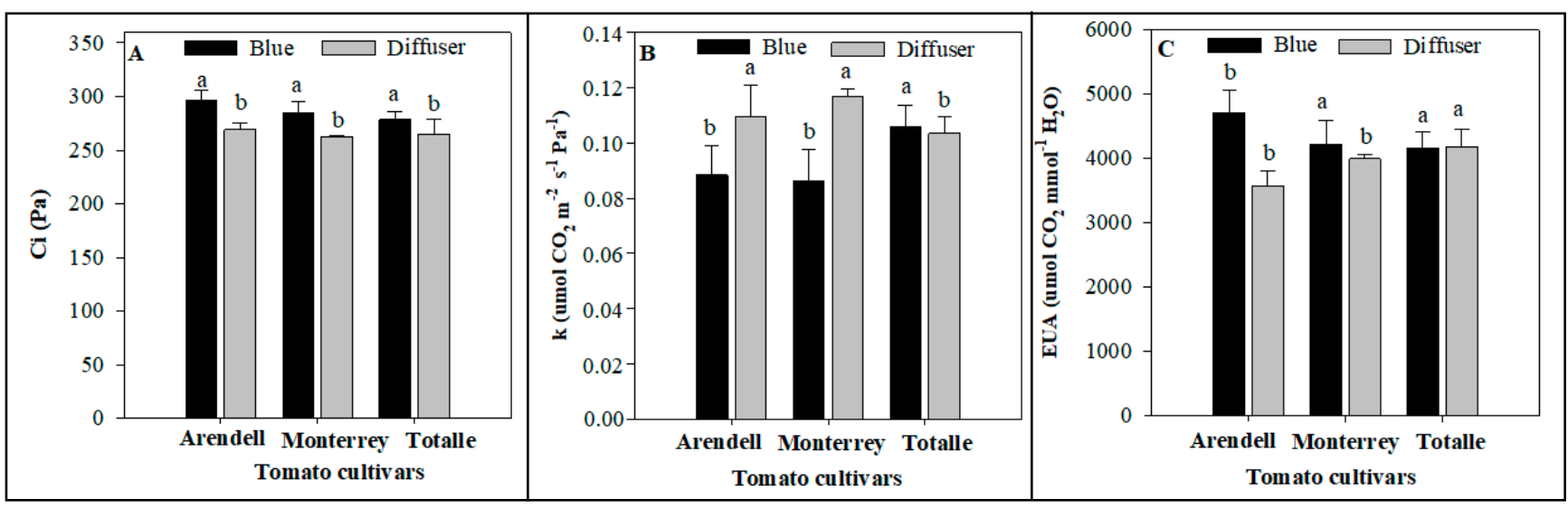

Figure 4. Intercellular $\mathrm{CO}_{2}$ concentration (A), instant carboxylation efficiency (B), water use efficiency (C) in relation to different agrofilms and tomato cultivars. Alfenas, UNIFENAS, 2018.

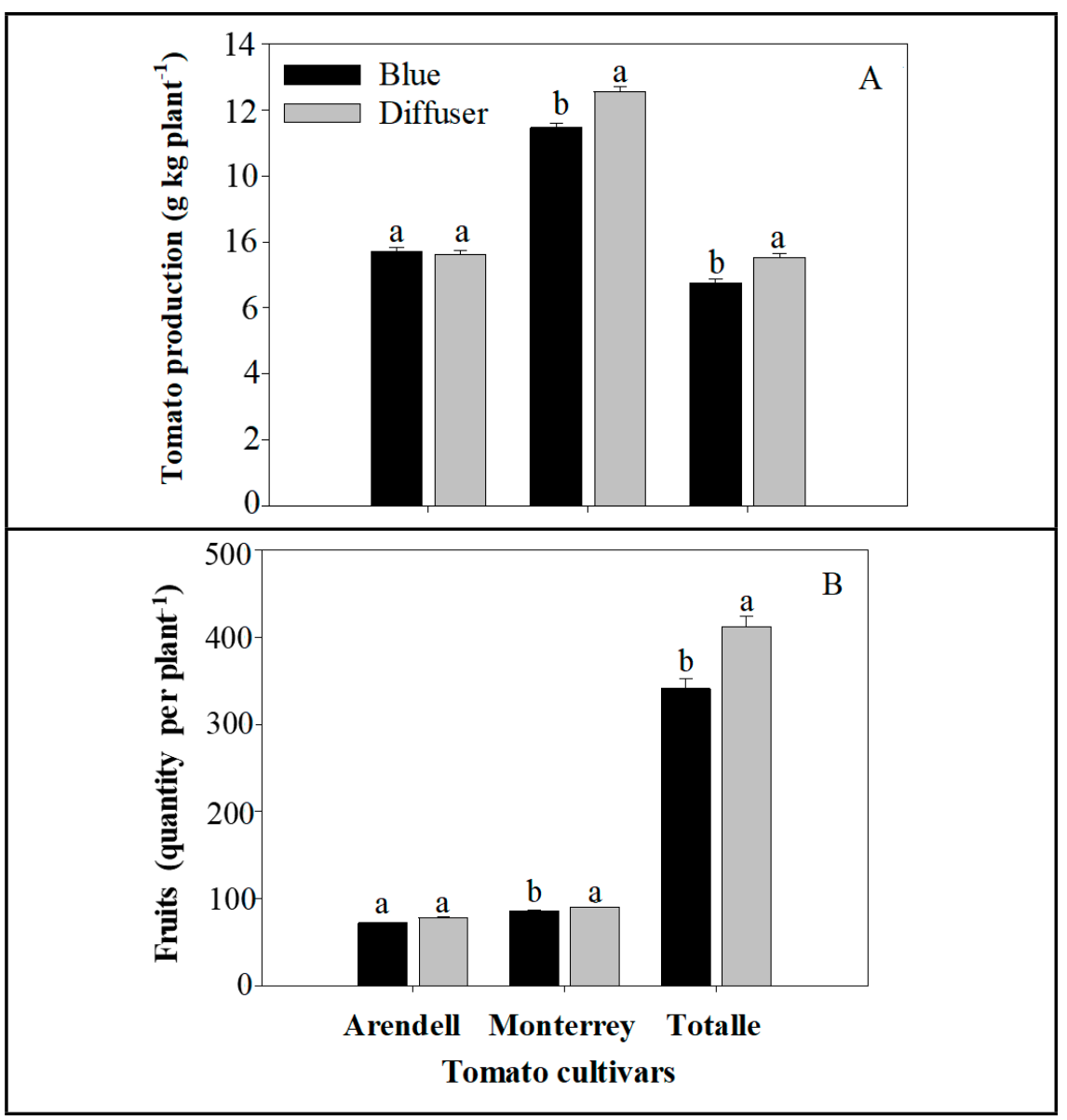

Figure 5. Tomato production (A) and fruits $(\mathrm{B})$ in relation to different agrofilms and tomato cultivars. Alfenas, UNIFENAS, 2018.

plant etiolation (Pinho et al., 2012), decreasing photoinhibition ( $\mathrm{Li}$ et al., 2012). The lower and intermediate leaves are favored by the use of diffused light, significantly improving their photosynthetic rates (Dueck et al., 2012). The lowest production observed with the use of the blue agrofilm may be related to radiation intensity (Figure 1) in the green zone, of the visible light spectrum, which may have caused greater elongation of stems and leaves, consequently reducing fruit production. This may also be related to the fact that tomato is a $\mathrm{C} 3$ plant, where maximum rate of photosynthesis is achieved at relatively low radiation intensity. Fruit $\mathrm{pH}$ did not range significantly with the use of agrofilms, for the studied cultivars (Figure 6A). Soluble solid contents in fruits, expressed in ${ }^{\circ}$ Brix, was higher for cultivars Monterrey and Totalle, regardless of the cultivation environment. For cultivar Arendell, the blue agrofilm provided higher soluble solid content in relation to the diffusing agrofilm (Figure 6B). Minimum contents observed in tomato juice should be $\mathrm{pH} 4.3$ and soluble solid content of $5^{\circ} \mathrm{Brix}$, at $20^{\circ} \mathrm{C}$ temperature (MAPA, 2018). According to Schwarz et al. (2013), fruits showing soluble solid content above $3^{\circ}$ Brix can be commercialized in fresh fruit markets. Lycopene content of the fruits (Figure 6C) was higher when the cultivars were grown in an environment covered with diffusing agrofilm. Considering qualitative trait, this is an important result, since lycopene belongs to the carotenoid family, which also includes beta-caroten, found in some fruits and vegetables, giving them a red color, and being usually present in large quantities in tomato fruits. Several studies point out the efficiency of lycopene as an antioxidant, inclusive relating this function to cancer prevention, especially prostate cancer (Soares \& Farias, 2012).

The authors concluded that the amount of radiation which passes through the diffusing agrofilm favors an increase, of around $18 \%$, in gas exchange, $12 \%$ in the lycopene content 


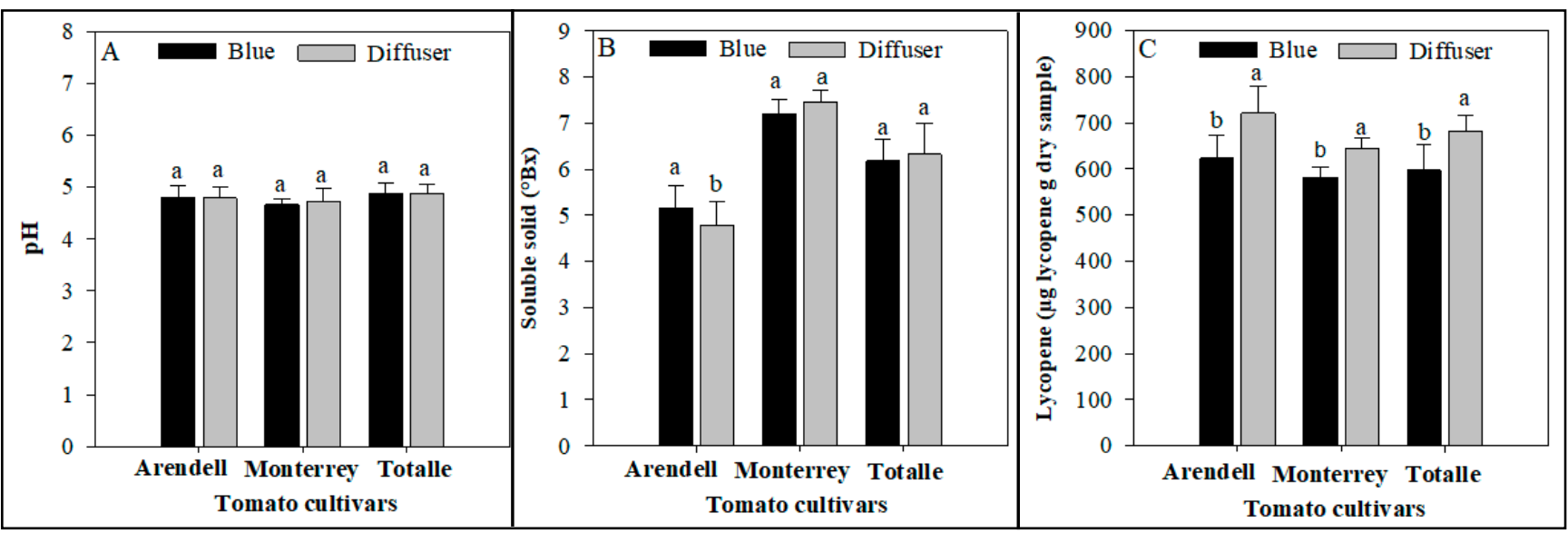

Figure 6. $\mathrm{pH}$ quantification (A), soluble solid content expressed in ${ }^{\circ}$ Brix $(\mathrm{B})$ and lycopene content in fruits $(\mathrm{C})$ of three tomato cultivars, grown under different agrofilms. Alfenas, UNIFENAS, 2018.

and $9.4 \%$ in tomato production.

\section{ACKNOWLEDGEMENTS}

The authors thank to Foundation for Research Support of Minas Gerais (FAPEMIG, Brazil) for the financial support for this study and the national council for scientific and technological development ( $\mathrm{CNPq}$, Brazil) for the scholarships granted for the first author.

\section{REFERENCES}

ANDRADE, WJS; FARIAS JÚNIOR, M; SOUSA, MA; ROCHA, AC. 2011. Utilização de diferentes filmes plásticos como cobertura de abrigos para cultivo protegido. Acta Scientiarum Agronomy 33: 437-443.

AOAC - Association of Official Analytical Chemistry. 2012. Official methods of analysis of the Association of Official Analytical Chemistry, Gaithersburg, Maryland. 3000p.

BOSCO, MRO; OLIVEIRA, AB; HERNANDEZ, FFF; LACERDA, CF. 2009. Efeito do $\mathrm{NaCl}$ sobre o crescimento, fotossíntese e relações hídricas de plantas de berinjela. Revista Ceres 56: 296-302

COBAPLA. 2018. 10 de novembro. Guia Brasileiro de Plasticultura. Available http:// cobapla.com.br/index.php/guia-brasileiro-deplasticultura. Accessed November 10, 2018.

CUNHA, AR; ESCOBEDO, JF; KLOSOWSKI, ES. 2002. Estimativa do fluxo de calor latente pelo balanço de energia em cultivo protegido de pimentão. Pesquisa Agropecuária Brasileira 37: 735-743.

DALEY, PF; RASCHKE, K; BALL, JY; BERRY, JA. 1989. Topography of photosynthetic activity of leaves obtained from video images of chlorophyll fluorescence. Plant Physiology 90: 1233-1238.
DOSSA, D; FUCHS, F. 2017. Tomate: análise técnico-econômica e os principais indicadores da produção nos mercados mundial, brasileiro e paranaense. Paraná: CEASA. 50p. (Boletim Técnico)

DUECK, T; JANSE, J; Li, T; KEMPKES, F; EVELEENS, B. 2012. Influence of diffuse glass on the growth and production of tomato. Acta Horticulturae 958: 75-82.

FERRAZ, RLS; MELO, AS; SUASSUNA, JF; BRITO, MEB; FERNANDES, PD; NUNES JÚNIOR, ES. 2012. Trocas gasosas e eficiência fotossintética em ecótipos de feijoeiro cultivados no semiárido. Revista Pesquisa Tropical 42: 181-188.

FERRARI, DL; LEAL, PAM. 2015. Uso de tela termorrefletora em ambientes protegidos para cultivo do tomateiro. Engenharia Agrícola 35: 180-191.

FERREIRA, D. 2011. Sisvar: um sistema computacional de análise estatística. Ciência Agrotecnologia 35:1039-1042.

GARY, C; BALDET, P; BERTIN, N; DEVAUX, C; TCHAMITCHIAN, M; RAYMOND, P. 2003. Time-course of tomato whole-plant respiration and fruit and stem growth during prolonged darkness in relation to carbohydrate reserves. Annals of Botany 91: 429-438.

GUISELINI, C; SENTELHAS, PC; OLIVEIRA, RC. 2004. Uso de malhas e sombreamento em ambiente protegido II: Efeito sobre a radiação solar global e a fotossinteticamente ativa no crescimento e produção da cultura de pimentão. Revista Brasileira de Agrometeorologia 11: 15-26.

JADOSKI, SO; KLAR, AE; SALVADOR, ED. 2005. Relações hídricas e fisiológicas em plantas de pimentão ao longo de um dia. Ambiência 1: 1-19.

KÄMPF, AN; CRUZ, FZ; COSTA, DA; HESSE, HH; VIELMO, HA; SILVA, L; PARADECA, MRAM; SCHNEIDER, PS; BASTOS, RM. 2000. Produção comercial de plantas ornamentais. $89 \mathrm{p}$.

PINHO, P; JOKINEN, K; HALONEN, L. 2012. Horticultural lighting - present and future challenges. Lighting Research and Technology 44: 427-437.
LI, T; HEUVELINK, E; DUECK, TA; MARCELIS, LFM. 2012. Understanding how diffuse light increases yield in tomato. ISHS Proc. 7th International Symposium on Light in Horticultural Systems, Leuven. Book of Abstracts. 98p.

LIMA, MA; BEZERRA, MA; GOMES, EF; PINTO, CM; ENÉAS, JF. 2010. Trocas gasosas em folhas de sol e sombreadas de cajueiro anão em diferentes regimes hídricos. Revista Ciência Agronômica 41: 654-663.

MAPA. 2018. Instrução Normativa $N^{\circ} 37$, de $1^{\circ}$ de Outubro de 2018. Available http:// www.in.gov.br/materia/-/asset_publisher/ Kujrw0TZC2Mb/content/id/44304943/do12018-10-08-instrucao-normativa-n-37-de-1de-outubro-de-2018-44304612

MAPA. 1995. Portaria $\mathrm{N}^{\circ} 553$, de 30 de agosto de 1995. available http://sistemasweb. agricultura.gov.br/sislegis/action/detalhaAto. do? method=visualizarAtoPortalMapa\&cha $\mathrm{ve}=1920192566$

MARQUES, DJ; LUZ, FDV; BARROSO, RWF; BIANCHINI, HC. 2018. Software for calculation of nutrient solution for fruits and leafy vegetables in NFT hydroponic system. In: Md. Asaduzzaman, $\mathrm{PhD} /$ Toshiki Asao (org). Potassium - Improvement of quality in fruits and vegetables through hydroponic nutrient management. $1^{\text {st }}$ ed. Rijeka, Croatia: In TechOpen 1: 20-34.

PAPADAKIS, G. 2000. Radiometric and thermal properties of, and testing methods for, greenhouse covering materials. Journal of Agricultural Engineering Research 77: 7-38.

POPOV, EG; TALANOV, AV; KURETS, VK; DROZDOV, SN. 2003. Effect of temperature on diurnal changes in $\mathrm{CO}_{2}$ Exchange in intact cucumber plants. Russian Journal of Plant Physiology 50: 178- 182.

RODRIGUEZ-AMAYA, DB. 2001. A Guide to Carotenoid Analysis in Foods. ILSI Human Nutrition Institute. One Thomas Circle, NW, Washington DC, 20005-5802, 64p.

SCHWARZ, K; RESENDE, JTV; PRECZENHAK, AP; PAULA, JT; FARIA, MV; DIAS, DM. 2013. Desempenho agronômico e qualidade físico-química de híbridos de tomateiro em 
cultivo rasteiro. Horticultura Brasileira 31: 410-418.

SHIMONO, H; SUZUKI, K; AOKI, K. 2010. Effect of panicle removal on photosynthetic acclimation under elevated $\mathrm{CO}_{2}$ in rice.
Photosynthetica 48: 530.

SOARES AP; FARIAS LM. 2012. Efeito do Licopeno do tomate na prevenção do câncer de próstata. Revista Interdisciplinar 5: 50-54. SOUSA, JW; MARTINS, D; CUNHA, AR;
ESCOBEDO, JF; GALVANI, E. 2002. Alterações da temperatura e umidade relativa do ar em ambiente protegido com cobertura de polietileno difusor de luz. Revista Brasileira de Agrometeorologia 10: 1-9. 